\title{
Color removal from yeast production industry wastewater using photo-fenton process
}

\section{Maya endüstrisi atıksılarından foto-fenton yöntemi ile renk giderimi}

\author{
Neval BAYCAN ${ }^{*}$ iD, Begüm $C A N^{2}$ iD \\ ${ }^{1}$ Environmental Engineering Department, Engineering Faculty, Dokuz Eylul University, Izmir, Turkey. \\ neval.baycan@deu.edu.tr \\ 2 Environmental Engineering Department, Engineering Faculty, Izmir Institute of Technology, Izmir, Turkey. \\ begumcan@iyte.edu.tr
}

\begin{abstract}
The yeast production industry wastewaters contains high amount of chemical oxygen demand (COD), brownish color and recalcitrant organic components. In this work, one of the yeast production plant wastewaters operating in the Aegean Region, the color removal were studied with using Photo-Fenton $\left(\mathrm{H}_{2} \mathrm{O}_{2} / \mathrm{Fe}(\mathrm{II}) / \mathrm{UV}\right)$ oxidation processes. In this study, the Box-Wilson statistical experimental design method applied to optimization of decolorisation of the yeast production industry wastewater. For this reason, the initial oxidant and catalyst concentrations and $\mathrm{pH}$ of water were chosen as the experimental parameters on decolorisation. Color removal was observed during the experimental studies. Complete color removal ( $E=100 \%)$ was achieved with the addition of $2400 \mathrm{mg} / \mathrm{L} \mathrm{H}_{2} \mathrm{O}_{2}$ and $121 \mathrm{mg} / \mathrm{L} \mathrm{Fe}(\mathrm{II})$ at $3.7 \mathrm{pH}$ after 120 min. of exposure to the UV irradiation.
\end{abstract}

Keywords: Photo-Fenton oxidation, Box-Wilson, Decolorisation, Yeast production industry

\section{Introduction}

In the yeast industry molasses is used as a raw material and much of the wastewater is generated from the processes of preparing molasses, separating and drying the yeast. In these industries it is possible to distinguish two main types of wastewater source. The first is process wastewater containing high organic loadings (COD, 80.000-100.000 mg/L, and BOD, 40.000-50.000 mg/L), strong odor and a large amount of dark brown color, apart from low pH 4-5 [1],[2]. The second is low to moderate process wastewater coming from cleaning. The dark brown color in these wastewaters is caused by the pigment called melanoidins which is resistant in nature, and it is not biodegradable [3],[4].

Some researchers studied color and COD removals from Bakery Yeast wastewater by using biological treatment alternatives. The higher removal in color was achieved after 4 days of the treatment and the best result was $43.01 \%$ [5]. This decolorisation of bakery yeast wastewater may be because of the degradation and/or adsorption of melanoidin and other color materials onto the cell walls and the mycelium. These studies have shown that this method was effective in COD removal but does not meet discharge limits in color removal.

Fouling problems may occur with membrane filtration [2],[6], and reverse osmosis generates a high salinity wastes that presents disposal difficulties [7]. Chemical coagulation and adsorption remove color and COD effectively, but they have a number of disadvantages such as; requirements of high amount

\section{Öz}

Maya üretim endüstrisinin atığı, yüksek miktarda kimyasal oksijen ihtiyacı (KOİ), azot, koyu renk ve biyolojik olarak parçalanmayan organik bileșikler içermektedir. Bu çalışmada, Ege Bölgesi'nde faaliyet gösteren bir maya sanayinin atıksularının, renk giderimi Foto-Fenton $\left(\mathrm{H}_{2} \mathrm{O}_{2} / \mathrm{Fe}\right.$ (II)/UV) oksidasyon yöntemi kullanılarak arıtılmaya çalıșılmiștır. Box-Wilson istatistiksel deneysel tasarım yöntemi kullanılarak başlangıç oksidan ve katalizör konsantrasyonları ve suyun pH'sı gibi bazı çalıșma parametrelerinin renk giderme üzerindeki etkileri araştırılmıştır. Çalışma süresince renk giderimi izlenmiş ve komple renk giderimi ( $E=\% 100) 120 \mathrm{dk}$. sonra, $3.7 \quad \mathrm{pH} \mathrm{H}^{\prime} \mathrm{da}$ $2400 \mathrm{mg} / \mathrm{L} \mathrm{H}_{2} \mathrm{O}_{2}$ ve $121 \mathrm{mg} / \mathrm{L} \mathrm{Fe}$ (II) ilavesinin olduğu UV oksidasyonu ișlemi sonucunda elde edilmiștir.

Anahtar kelimeler: Foto-Fenton oksidasyou, Box-Wilson, Renk giderimi, Maya endüstrisi

of inorganic coagulants and high cost of regeneration of adsorbent [8]. Decolorisation through chemical treatment with ozone [9],[10], Fenton's reagent [10] and $\mathrm{H}_{2} \mathrm{O}_{2}$ /UV [11] leads to temporary color reduction because of transformation of the chromospheres groups. Therefore, strong oxidising methods such as photo-fenton are needed to be applied on color removal. The current standard defined discharge limit, observing and control requirement for water pollutants of yeast industry. The current standard is suitable for discharge control of water pollutants from yeast industries. According to Turkish Water Pollution and Control Regulations, Yeast Production industry wastewaters have to be decolorized. In this study, color of the yeast production industry wastewater treated by using $\mathrm{UV} / \mathrm{H}_{2} \mathrm{O}_{2} / \mathrm{Fe}(\mathrm{II})$ (photo-fenton) to achieve discharge standards.

\section{Materials and methods}

2.1 The yeast production industry wastewater characterization

The Yeast Production wastewater samples were taken from the Yeast Production company treatment plant, located in Izmir, Turkey. Samples were obtained from effluent of anaerobicaerobic ponds. Composition of the wastewater used in this study was determined before experimental studies. The $\mathrm{pH}$ values of the yeast production industry effluent samples used in the experimental studies varied from 7.00 to 7.85 . COD concentrations of samples varied from $750 \mathrm{mg} / \mathrm{L}$ to $850 \mathrm{mg} / \mathrm{L}$, TOC concentrations of samples varied from $200 \mathrm{mg} / \mathrm{L}$ to 
$250 \mathrm{mg} / \mathrm{L}$ and TSS were varied between $90-100 \mathrm{mg} / \mathrm{L}$ The wastewater characterizations meet to discharges standards for COD and pH other parameters except from color according to Turkish Water Pollution and Control Regulations. The color of the wastewater was dark brown.

\subsection{Materials}

Analytical grade (Merck) iron sulphate $\left(\mathrm{FeSO}_{4}\right)$ was chosen as a catalyst to obtain $\mathrm{Fe}(\mathrm{II})$. The hydrogen peroxide $\left(\mathrm{H}_{2} \mathrm{O}_{2}\right)$ (Merck) was used as an oxidant and it was a stable form $(35 \%, w / w)$. A $10 \mathrm{~g} / \mathrm{L}$ iron (II) solution was prepared for use in the experiments and diluted to the desired concentration. The $\mathrm{Fe}(\mathrm{II})$ stored in a closed board to avoid the changes of Fe(II) because of oxidation with light. The excess $\mathrm{H}_{2} \mathrm{O}_{2}$ in the collected aqueous samples was destroyed with the addition of $\mathrm{MnO}_{2}$. For the $\mathrm{pH}$ adjustment either $0.01 \mathrm{M} \mathrm{HCl}$ or $0.01 \mathrm{M} \mathrm{NaOH}$ was used.

\subsection{Photo-Reactor and experimental procedure}

The photocatalytic reactions were set up, as shown in Figure 1, in a $100 \mathrm{ml}$ reaction volume with a $2 \mathrm{~cm}$ stirrer. Five Phillips UVC ( 8 watts each) lamps were used as light sources of the photo-Fenton reaction, the measured intensities for the UVC light $32 \mathrm{w} / \mathrm{m}^{2}$ at just below the lamps and $26 \mathrm{w} / \mathrm{m}^{2}$ at the top of the reactor. $100 \mathrm{ml}$ of wastewater was adjusted to the desired $\mathrm{pH}$ using $0.01 \mathrm{M} \mathrm{HCl}$ and $0.01 \mathrm{M} \mathrm{NaOH}$. Fe (II) catalyst was added to the wastewater after $\mathrm{pH}$ adjustment. The UV lamps were only turned on once desired of hydrogen peroxide $\left(\mathrm{H}_{2} \mathrm{O}_{2}\right)$ had been added. The degradation of color was measured by a Varian Cary 50 UV-VIS spectrophotometer at appropriate time intervals at a wavelength of $465 \mathrm{~nm}$. Samples were filtered through a Millipore $0.22 \mu \mathrm{m}$ filter using a $10 \mathrm{ml}$ syringe to prevent catalyst interference with absorbance readings. Each experiment repeated tree times and mean value of the results were given.

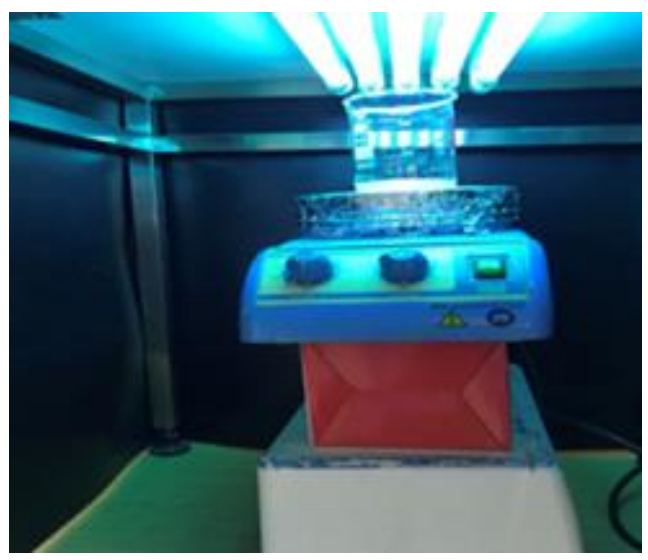

Figure 1: Experimental set-up.

\subsection{Methods}

Color measurements were done according to the PlatinumCobalt Scale (Pt/Co scale or Apha-Hazen Scale). The Pt/Co scale was advanced as a way to measure pollution levels in wastewater. It is certain to the color yellow and is based on dilutions of a $500 \mathrm{mg} / \mathrm{L}$ platinum cobalt solution. Color measurements were carried at the wavelength $465 \mathrm{~nm}$ as given in ASTM Methods [12].

\subsection{Statistical design}

The Box-Wilson statistical method for experimental design (RSM) was applied according to procedure given by Baycan et al [9].
$\mathrm{H}_{2} \mathrm{O}_{2}$ (X1) and $\mathrm{Fe}(\mathrm{II})$ (X2) concentrations and $\mathrm{pH}$ (X3) were chosen as independent variables. Color removal efficiency was considered as dependent variable in the RSM.

The $\mathrm{H}_{2} \mathrm{O}_{2}$ concentration (X1) was changed from $1981 \mathrm{mg} / \mathrm{L}$ to $3962 \mathrm{mg} / \mathrm{L}$, the $\mathrm{Fe}(\mathrm{II})$ concentration (X2) varied between $50 \mathrm{mg} / \mathrm{L}$ and $140 \mathrm{mg} / \mathrm{L}$ and $\mathrm{pH}$ (X3) between 2.5 and 4. From the literature it is known that [6] photo-fenton oxidation is working better under acidic $\mathrm{pH}$ ranges. In the light of this information, to optimize the $\mathrm{pH}$ value exactly, $\mathrm{pH}$ was chosen as an independent variable in a small range. Table 1 shows the experimental conditions founded by the Box-Wilson statistical design.

Table 1: Experimental conditions.

\begin{tabular}{cccc}
\hline No & $\mathrm{H}_{2} \mathrm{O}_{2}(\mathrm{mg} / \mathrm{L})$ & $\mathrm{Fe}^{2+}(\mathrm{mg} / \mathrm{L})$ & $\mathrm{pH}$ \\
\hline $\mathrm{A} 1$ & 3962 & 95 & 3.25 \\
$\mathrm{~A} 2$ & 1981 & 95 & 3.25 \\
$\mathrm{~A} 3$ & 2972 & 140 & 3.25 \\
$\mathrm{~A} 4$ & 2972 & 50 & 3.25 \\
$\mathrm{~A} 5$ & 2972 & 95 & 4.00 \\
$\mathrm{~A} 6$ & 2972 & 95 & 2.50 \\
$\mathrm{~F} 1$ & 3543 & 121 & 3.68 \\
$\mathrm{~F} 2$ & 3543 & 121 & 2.82 \\
$\mathrm{~F} 3$ & 3543 & 69 & 3.68 \\
$\mathrm{~F} 4$ & 3543 & 69 & 2.82 \\
$\mathrm{~F} 5$ & 2400 & 121 & 3.68 \\
$\mathrm{~F} 6$ & 2400 & 121 & 2.82 \\
$\mathrm{~F} 7$ & 2400 & 69 & 3.68 \\
$\mathrm{~F} 8$ & 2400 & 69 & 2.82 \\
$\mathrm{C}$ & 2972 & 95 & 3.25 \\
\hline
\end{tabular}

The following equation was used in the calculation of the color removal yield $(\mathrm{Y})$ depending on the determined independent parameters (X1, X2, X3).

$$
\begin{gathered}
\mathrm{Y}=\mathrm{b} 0+\mathrm{b} 1 \mathrm{X} 1+\mathrm{b} 2 \mathrm{X} 2+\mathrm{b} 3 \mathrm{X} 3+\mathrm{b} 12 \mathrm{X} 1 \mathrm{X} 2+\mathrm{b} 13 \mathrm{X} 1 \mathrm{X} 3+ \\
\mathrm{b} 23 \mathrm{X} 2 \mathrm{X} 3+\mathrm{b} 11 \mathrm{X} 12+\mathrm{b} 22 \mathrm{X} 22+\mathrm{b} 33 \mathrm{X} 32
\end{gathered}
$$

The STATISTICA computer program was employed for the determination of the coefficients by regression analysis of the experimental data for each where; $\mathrm{Y}$ is predicted yield, $\mathrm{b}_{0}$ is constant, $b_{1}, b_{2}$ and $b_{3}$ are linear coefficients, $b_{12}, b_{13}$ and $b_{23}$ are cross product coefficients and $b_{11}, b_{22}$ and $b_{33}$ are quadratic coefficients. Experimental results were used to determine the coefficients of the response functions; the determined coefficients were used in calculating predicted values of color removal efficiencies (Eq. 1).

\section{Results and discussion}

The main purpose of Photo-Fenton oxidation is to produce hydroxyl radical. With a mixture of $\mathrm{H}_{2} \mathrm{O}_{2}$ and $\mathrm{Fe}$ (II) ions and ultraviolet light, the production of hydroxyl radical is increased, which makes oxidation more efficient. In this work, a series of studies were made with Photo-Fenton oxidation to examine the inceptive $\mathrm{H}_{2} \mathrm{O}_{2}$, iron (II) dosage, and the effects of $\mathrm{pH}$ on color removal from yeast production wastes.

The color degradation rates achieved from the experiments were given in Table 2. The coefficients obtained from STATISTICA regression analysis program, were used to calculate predicted values of decolorisaiton efficiencies. The correlation coefficient $\left(\mathrm{R}^{2}\right)$ between the calculated values and the values found in the experimental studies was 0,97 . This is an indication that the removal efficiencies are consistent with each other. 
Ycolor $=99.85873+0.42268 *\left(\mathrm{H}_{2} \mathrm{O}_{2}\right)+0.39274 * \mathrm{Fe}(\mathrm{II})+0.23965^{*}$ $(\mathrm{pH})+1.70960 \mathrm{E}-016 *\left(\mathrm{H}_{2} \mathrm{O}_{2} * \mathrm{Fe}(\mathrm{II})\right)+1.00 *\left(\mathrm{H}_{2} \mathrm{O}_{2} * \mathrm{pH}\right)-$ $1.86190 \mathrm{E}-016^{*}(\mathrm{Fe}(\mathrm{II}) * \mathrm{pH})-0.95688^{*}\left(\mathrm{H}_{2} \mathrm{O}_{2}\right)^{2-}$ $0.42854^{*}(\mathrm{Fe}(\mathrm{II}))^{2}-1.13565^{*}(\mathrm{pH})^{2}$

Table 2: Color removal efficiencies.

\begin{tabular}{ccc}
\hline & \multicolumn{2}{c}{ Color Removal (\%) } \\
\cline { 2 - 3 } Analysis No & Observed & Predicted \\
\hline A1 & 99 & 98 \\
A2 & 92 & 96 \\
A3 & 98 & 99 \\
A4 & 96 & 98 \\
A5 & 93 & 97 \\
A6 & 97 & 96 \\
F1 & 100 & 99 \\
F2 & 96 & 97 \\
F3 & 100 & 99 \\
F4 & 95 & 96 \\
F5 & 100 & 97 \\
F6 & 99 & 98 \\
F7 & 99 & 96 \\
F8 & 99 & 97 \\
C1 & 100 & 100 \\
C2 & 100 & 100 \\
C3 & 100 & 100 \\
C4 & 100 & 100 \\
\hline
\end{tabular}

It is important to know the applicability of the model to check the accuracy of the results. Table 3 depicts the Analysis of Variance (ANOVA) outcomes of the proven model for color removal efficiencies.

Table 3: ANOVA results for RSM.

$\begin{array}{cllll}\text { Parameter } & \text { Source } & \begin{array}{l}\text { Sum of } \\ \text { Squares }\end{array} & F \text {-value } & \text { Prob }>F \\ & \text { Model } & 69.17 & 2.51 & 0.0084 \\ & \text { Residual } & 30.58 & & \\ \begin{array}{c}\text { Color } \\ \text { Removal }\end{array} & \text { Lack of fit } & 30.58 & 4.42 & \\ & \text { Pure error } & 0.00 & & \\ & \mathrm{R}^{2}=0.97 & & & \end{array}$

The ANOVA results evaluation procedure was done according to our previous studies [10]. The model F-value (Fisher variation ratio), probability value (Prob $>F$ ) and adequate precision are the main indicators showing the significance and adequacy of the employed model. The model F-value was calculated by dividing the model mean square by residual mean square. Values of Prob > F less than 0.0500 imply that the model is significant, whereas the values greater than 0.1000 are usually considered as insignificant. Prob $>F$ values of 0.0084 means the calculated models are significant for decolorisation. Table 3 proves that the correlation coefficients, $\mathrm{R}^{2}$, adjusted $\mathrm{R}^{2}$, and predicted $\mathrm{R}^{2}$ are near to each other and close to 1.0. If the $\mathrm{P}$ values are $>0.05$, the statistical significance of $F$ is insignificant, i.e., there is a significant agreement between the variables determined in the model and the experimental results (Table 3).

According to Turkish Water Pollution and Control Regulations, the color parameter should be below $260 \mathrm{Pt}$-Co. It could be seen on Table 4, all experiments could be achieved discharge standards.
After the evaluation of color removal experiments, TOCs were measured at high removal efficiencies obtained points. The TOC removal efficiencies were between $75 \%-80 \%$. In another study [11], only $82 \%$ color removal and $70 \%$ TOC removal efficiency was obtained for $\mathrm{UV} / \mathrm{H}_{2} \mathrm{O}_{2} / \mathrm{Fe}(\mathrm{II})$ process.

Additional work has been done to see the effects of the variables on the color removal efficiency, except for the experimental points. In these studies, one variable was kept constant and the other two variables were given different values according to the intervals used in the statistical design, and the color removal efficiency was calculated for these points.

Table 4: Removal efficiencies and Pt-Co concentrations.

\begin{tabular}{cccccc}
\hline No & $\begin{array}{c}\mathrm{H}_{2} \mathrm{O}_{2} \\
(\mathrm{mg} / \mathrm{L})\end{array}$ & $\begin{array}{c}\mathrm{Fe}^{2+} \\
(\mathrm{mg} / \mathrm{L})\end{array}$ & $\mathrm{pH}$ & $\begin{array}{l}\% \\
\text { Rem. } \\
\text { Eff. }\end{array}$ & Pt-Co \\
& & & \multicolumn{3}{c}{} \\
\hline A1 & 3962 & 95 & 3.25 & 99 & 143 \\
$\mathrm{~A} 2$ & 1981 & 95 & 3.25 & 92 & 151 \\
$\mathrm{~A} 3$ & 2972 & 140 & 3.25 & 98 & 121 \\
A4 & 2972 & 50 & 3.25 & 96 & 128 \\
A5 & 2972 & 95 & 4.00 & 93 & 143 \\
A6 & 2972 & 95 & 2.50 & 97 & 142 \\
F1 & 3543 & 121 & 3.68 & 100 & 130 \\
F2 & 3543 & 121 & 2.82 & 95 & 155 \\
F3 & 3543 & 69 & 3.68 & 100 & 109 \\
F4 & 3543 & 69 & 2.82 & 99 & 140 \\
F5 & 2400 & 121 & 3.68 & 99 & 115 \\
F6 & 2400 & 121 & 2.82 & 99 & 120 \\
F7 & 2400 & 69 & 3.68 & 100 & 97 \\
F8 & 2400 & 69 & 2.82 & 100 & 119 \\
C & 2972 & 95 & 3.25 & 100 & 100 \\
\hline
\end{tabular}

\subsection{Effect of Fe(II)}

$\mathrm{H}_{2} \mathrm{O}_{2}$ concentration and the $\mathrm{Fe}(\mathrm{II})$ concentration were varied between $1981 \mathrm{mg} / \mathrm{L}$ and $3962 \mathrm{mg} / \mathrm{L}, 69.02 \mathrm{mg} / \mathrm{L}$ and $140 \mathrm{mg} / \mathrm{L}$ in this experiments, respectively, while the $\mathrm{pH}$ was constant at 3.7. Differences of percent color degradations from the yeast production wastewater with $\mathrm{H}_{2} \mathrm{O}_{2}$ concentrations are showed in Figure 2.

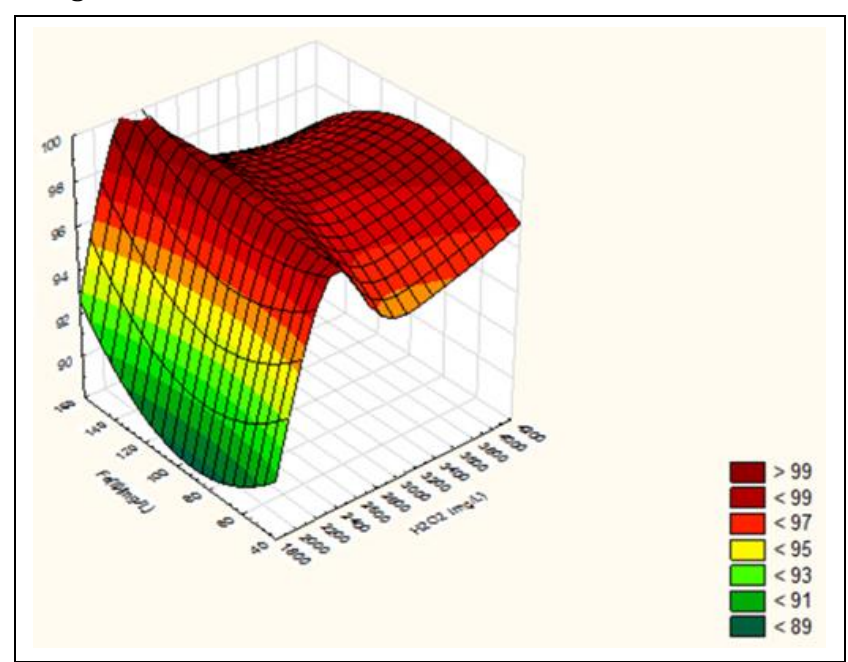

Figure 2: Color removal efficiency as a function of Fe(II) concentrations at different $\mathrm{H}_{2} \mathrm{O}_{2}$ concentrations ( $\left.\mathrm{pH}=3.7\right)$.

With increased iron (II) concentration (121 mg/L), the color removal yield has increased to a certain point, but the yield has also decreased with the additional iron. It could be clarified by 
the reaction of excess hydrogen peroxide or $\mathrm{Fe}(\mathrm{II})$ with $\bullet \mathrm{OH}$, as given in the following equations [13].

$$
\begin{gathered}
\mathrm{H}_{2} \mathrm{O}_{2}+\bullet \mathrm{OH} \rightarrow \mathrm{H}_{2} \mathrm{O}+\mathrm{HO}_{2} \bullet \\
\mathrm{Fe}^{2+}+\bullet \mathrm{OH} \rightarrow \mathrm{OH}^{-}+\mathrm{Fe}^{3+}
\end{gathered}
$$

The highest percent color removal was $100 \%$ after 120 minutes of oxidation with a $\mathrm{H}_{2} \mathrm{O}_{2} / \mathrm{Fe}(\mathrm{II})$ molar ratio of 33 . In other study, finest molar ratio in Fenton oxidation was found as 20-40 [8],[9].

\subsection{Effect of $\mathrm{H}_{2} \mathrm{O}_{2}$}

A series of experiments with $\mathrm{UV} / \mathrm{H}_{2} \mathrm{O}_{2}$ were performed with variable $\mathrm{H}_{2} \mathrm{O}_{2}$ concentration at different $\mathrm{pH}$ and at a constant $\mathrm{Fe}(\mathrm{II})$ concentration (121 mg/L). Figure 3 shows decolorisation of the Yeast Production industry wastewaters with different $\mathrm{H}_{2} \mathrm{O}_{2}$ concentration at constant initial Fe(II), oxidation time of 120 minutes. Addition of $\mathrm{H}_{2} \mathrm{O}_{2}$ to the UV system enhanced color removals. Color removal efficiency considerably increased with $\mathrm{H}_{2} \mathrm{O}_{2}$ concentration up to $2400 \mathrm{mg} / \mathrm{L}$ and then decreased with further increases in $\mathrm{H}_{2} \mathrm{O}_{2}$. At high concentrations, $\mathrm{H}_{2} \mathrm{O}_{2}$ acted as a radical scavenger so affecting decreases in the $\bullet \mathrm{OH}$ radical [7],[8].

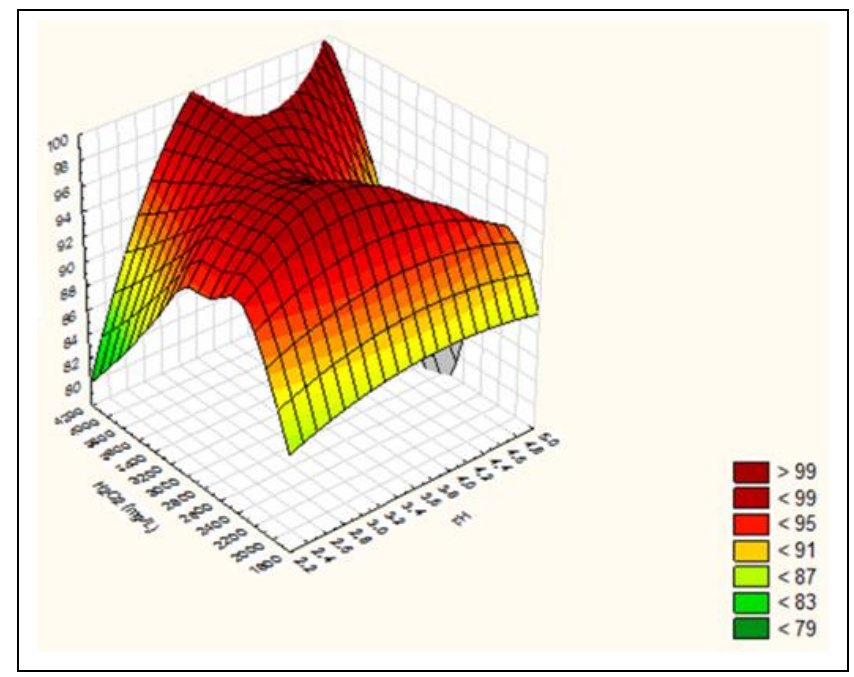

Figure 3: Color removal efficiency as a function of $\mathrm{H}_{2} \mathrm{O}_{2}$ concentrations at different $\mathrm{pH}(\mathrm{Fe}(\mathrm{II})=121 \mathrm{mg} / \mathrm{L})$.

The perhydroxyl radicals $\left(\mathrm{HO}_{2} \bullet\right)$ produced in Eq. (2) potentially reduced the available active hydroxyl radicals by further scavenging $\bullet \mathrm{OH}$, as shown in Eq. (4):

$$
\mathrm{HO}_{2} \bullet+\bullet \mathrm{OH} \rightarrow \mathrm{H}_{2} \mathrm{O}+\mathrm{O}_{2}
$$

\subsection{Effect of $\mathbf{p H}$}

With the purpose of define the effect of $\mathrm{pH}$ on decolorisation at a constant $\mathrm{H}_{2} \mathrm{O}_{2}$ concentration, some results were forecasted by means of response results with determined constants. The decolorisations were significantly enhanced with the ferrous salt addition and at $\mathrm{pH}$ 3.7. Figure 4 depict changes of color removal efficiencies with the different iron (II) concentration and different $\mathrm{pH}$ at a constant initial $\mathrm{H}_{2} \mathrm{O}_{2}$ of $2400 \mathrm{mg} / \mathrm{L}$ for the reaction time of $120 \mathrm{~min}$.

The highest decolorisation efficiency was achieved as $100 \%$ in $120 \mathrm{~min}$. at a Fe(II) concentration of $121 \mathrm{mg} / \mathrm{L}$ and $\mathrm{pH}$ 3.7. In other study, $\mathrm{pH} 3$ was found also the optimum $\mathrm{pH}$ for color removal of the Yeast Production industry [9].

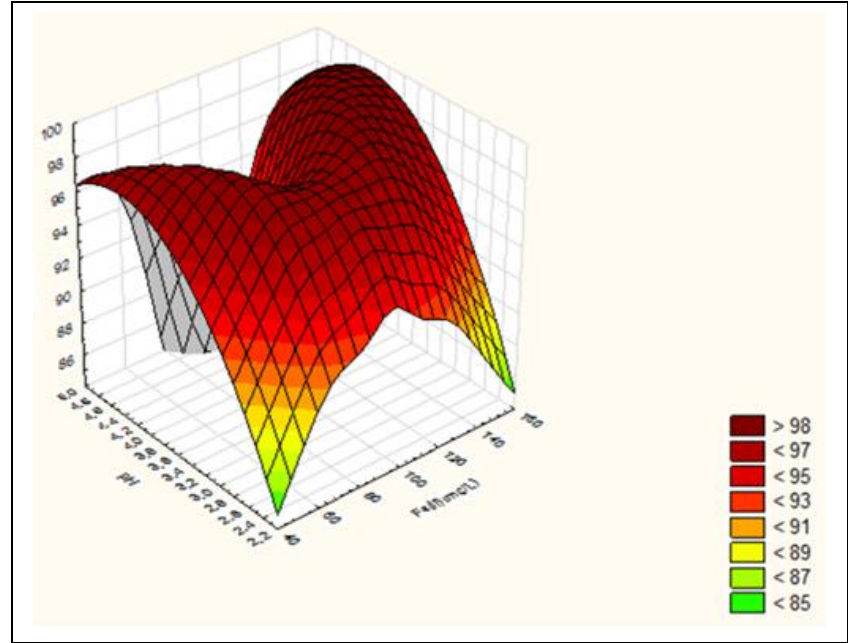

Figure 4: Color removal efficiency as a function of $\mathrm{pH}$ at different $\mathrm{Fe}(\mathrm{II})$ concentrations $\left(\mathrm{H}_{2} \mathrm{O}_{2}=2400 \mathrm{mg} / \mathrm{L}\right)$.

\section{Conclusions}

As a results of the experiments, it was determined that Fe(II) and $\mathrm{H}_{2} \mathrm{O}_{2}$ concentrations are significant parameters for decolorisation of the Yeast Production industry wastewaters. In order to determine the effects of hydrogen peroxide, catalyst and $\mathrm{pH}$ in advanced oxidation processes, a Box-Wilson statistical experimental design was used by considering the $\mathrm{pH}$, oxidant, catalyst as independent. The objective function was the color removal efficiencies.

The UV irradiation caused the generation of hydroxyl radicals as iron (II) does. Nevertheless, the excess iron concentration ( $>121 \mathrm{mg} / \mathrm{L}$ ) decreased the removal efficiency because of the turbidity.

The highest color removal was obtained with $2400 \mathrm{mg} / \mathrm{L} \mathrm{H}_{2} \mathrm{O}_{2}$ concentration. This concentration be similar to about $2.125 \mathrm{~g}$ $\mathrm{H}_{2} \mathrm{O}_{2}$ /g COD removed. Therefore, there is a significant correlation with the hypothetical $\mathrm{O}_{2}$ requirement per $\mathrm{g}$ of Chemical oxygen demand $\left(1 \mathrm{~g} \mathrm{O}_{2} / \mathrm{g}\right.$ COD which corresponds to $2.125 \mathrm{~g} \mathrm{H}_{2} \mathrm{O}_{2}$ / g COD). It is not necessary to add extra $\mathrm{H}_{2} \mathrm{O}_{2}$ for the color removal of the yeast production wastewater.

The optimal conditions up to $100 \%$ color removal of the yeast production was determined as $2400 \mathrm{mg} / \mathrm{L} \mathrm{H}_{2} \mathrm{O}_{2}$ and $121 \mathrm{mg} / \mathrm{L}$ $\mathrm{Fe}(\mathrm{II})$ concentration at $\mathrm{pH}$ 3.7. And under these conditions $80 \%$ TOC mineralization was obtained.

\section{References}

[1] Gengec E, Kobya M, Demirbas E, Akyol A, Oktor K. "Optimization of baker's yeast wastewater using response surface methodology by electrocoagulation". Desalination, 286, 200-209, 2012.

[2] Sowmeyan R, Swaminathan G. "Effluent treatment process in molasses-based distillery industries: a review". Journal Hazard Mater, 152(2), 453-464, 2008.

[3] Gladchenko M, Starostina E, Shcherbakov S, Versprille B, Kalyuzhnyi S. "Combined biological and physico-chemical treatment of baker's yeast wastewater including removal of coloured and recalcitrant to biodegradation pollutants". Water Science and Technology, 50, 67-76, 2004.

[4] Kalyuzhnyi S, Gladchenko M, Starostina E, Shcherbakov S, Versprille A. "Combined biological and physico-chemical treatment of baker's yeast wastewater". Water Science and Technology., 52, 1751832005. 
[5] Pirsaheba M, Rostamifar M, Mansouria AM, Zinatizadehd AAL, Sharafie K. "Performance of an anaerobic baffled reactor (ABR) treating high strength baker's yeast manufacturing wastewater". Journal of the Taiwan Institute of Chemical Engineers, 47, 137-146 2015.

[6] Baycan NP, Akten D. "Response surface methodological approach and the kinetic study for the assessment of the photodegradation of a pulp mill effluent with $\mathrm{H}_{2} \mathrm{O}_{2}$ /Fe(III)/Solar UV". FEB, 20(6), 1390-1398, 2011.

[7] Solozhenko EG, Soboleva NM, Goncharuk VV. "Decolorisation of azo dye solutions by Fenton's oxidation". Water Research, 29, 2206-2215, 1995.

[8] Asaithambi P, Sajjadi B, Abdul Aziz AR. "Ozone $\left(\mathrm{O}_{3}\right)$ and sono (US) based advanced oxidation processes for the removal of color, COD and determination of electrical energy from landfill leachate". Separation and Purification Technology, 172, 442-450, 2017.

[9] Gengec E. "Color removal from anaerobic/aerobic treatment effluent of bakery yeast wastewater by polyaniline/beidellite composite materials". Journal of Environmental Chemical Engineering, 3, 2484-2290, 2015.
[10] Baycan NP, Uyguner CD, Bekbölet M. "Response surface methodological approach for the assessment of the photocatalytic degradation of NOM". Journal of Photochemistry and Photobiology A: Chemistry, 225(1), 26-35, 2011.

[11] Catalkaya EC, Sengül F. "Application of Box-Wilson experimental design method for the photodegradation of bakery's yeast industry with $\mathrm{UV} / \mathrm{H}_{2} \mathrm{O}_{2}$ and $\mathrm{UV} / \mathrm{H}_{2} \mathrm{O}_{2} / \mathrm{Fe}(\mathrm{II})$ process". Journal of Hazardous Materials B, 128, 201-207, 2006.

[12] ASTM International standards. "Standard Test Method for Color of Clear Liquids (Platinum-Cobalt Scale)". ASTM, D212909-17, Washington, D.C, 2017.

[13] Asaithambi P, Sajjadi B, Abdul Aziz AR. "Integrated ozonephoto-Fenton process for the removal of pollutant from industrial wastewater". Chinese Journal of Chemical Engineering, 25, 516-525, 2017. 